\title{
Diagnosis dan Tatalaksana Terkini Penyakit Jantung Hipertensi
}

\author{
Brigita L. M. Moningka, ${ }^{1}$ Starry H. Rampengan, ${ }^{2}$ Edmond L. Jim ${ }^{2}$
}

\author{
${ }^{1}$ Program Studi Pendidikan Dokter Fakultas Kedokteran Universitas Sam Ratulangi, Manado, \\ Sulawesi Utara, Indonesia \\ ${ }^{2}$ Bagian Ilmu Penyakit Jantung dan Pembuluh Darah Fakultas Kedokteran Universitas Sam \\ Ratulangi, Manado, Sulawesi Utara, Indonesia \\ Email: brigitamoningkaa@gmail.com
}

\begin{abstract}
Hypertensive heart disease is a response to a prolonged increase in blood pressure that causes various changes in the myocardial structure. This study was aimed to obtain the recent diagnosis and management of hypertensive heart disease. This was a literature review study using 4 databases, as follows: Pubmed, Clinical Key, Science Direct, and Google Scholar. The keywords used were Hypertensive Heart Disease diagnosis of Hypertensive heart disease OR Screening of hypertensive heart disease OR imaging of hypertensive heart disease AND therapy OR treatment OR management of hypertensive heart disease. The results showed that there were 10 literatures that fulfilled the criteria, consisting of 6 randomized controlled trials and 4 article reviews. Among patients with hypertensive heart disease, left ventricle hypertrophy, left ventricular dilation, and diastolic and systolic disfunction were the most commonly found in ECG, echocardiography, chest X-ray, and CMR. Therapy of hypertensive heart disease was according to ACC/AHA guidelines with non-pharmacological therapy by adopting the DASH diet and pharmacological therapy of choice was ACE-I or ARB. In conclusion, in hypertensive heart disease, the most common structural changes were left ventricle hypertrophy, left ventricular dilation, diastolic and systolic disfunction found in ECG, echocardiography, chest X-ray, and CMR. Therapy of hypertensive heart disease was according to ACC/AHA guidelines.
\end{abstract}

Keywords: hypertensive heart disease

\begin{abstract}
Abstrak: Penyakit jantung hipertensi merupakan respon terhadap peningkatan tekanan darah berkepanjangan yang menyebabkan berbagai perubahan pada struktur miokard. Penelitian ini bertujuan untuk mendapatkan diagnosis dan tatalaksana terkini mengenai penyakit jantung hipertensi. Jenis penelitian ialah literature review menggunakan 4 database, yaitu Pubmed, Clinical Key, Science Direct, dan Google Scholar. Kata kunci yang digunakan ialah Hypertensive Heart Disease diagnosis of Hypertensive heart disease OR Screening of hypertensive heart disease OR imaging of hypertensive heart disease AND therapy OR treatment OR management of hypertensive heart disease. Hasil penelitian mendapatkan 10 literatur yang memenuhi kriteria penelitian, terdiri dari 6 randomized controlled trial dan 4 review article. Pada penyakit jantung hipertensi kelainan struktural yang sering ditemukan ialah hipertrofi ventrikel kiri (konsentrik maupun eksentrik), dilatasi ventrikel kiri, disfungsi diastolik dan sistolik, yang dapat dideteksi lewat pemeriksaan EKG, ekokardiografi, rontgen toraks, dan CMR. Terapi penyakit jantung hipertensi menurut pedoman ACC/AHA yakni nonfarmakologi seperti pola diet DASH dan terapi farmakologi pilihan yaitu ACE-I atau ARB. Simpulan penelitian ini ialah pada penyakit jantung hipertensi terdapat hipertrofi ventrikel kiri, dilatasi ventirkel kiri, disfungsi diastolik maupun sistolik, dideteksi menggunakan EKG, ekokardiografi, rontgen toraks dan CMR. Terapi penyakit jantung hipertensi sesuai dengan pedoman penatalaksanaan ACC/AHA.
\end{abstract}

Kata kunci: penyakit jantung hipertensi 


\section{PENDAHULUAN}

Hipertensi merupakan suatu keadaan dimana terjadi peningkatan tekanan darah yang bermanifestasi terhadap gangguan pada keseimbangan hemodinamik jantung dengan penyebab multifaktor. ${ }^{1}$

Menurut World Health Organization, sejumlah 1,13 miliar orang di dunia menyandang hipertensi, $2 / 3$ di antaranya tinggal di negara dengan pendapatan perkapita rendah dan menengah. Selain itu, hipertensi merupakan salah satu penyebab utama kematian di dunia, dan menyebabkan setidaknya $45 \%$ kematian karena penyakit jantung. WHO mengestimasikan prevalensi hipertensi secara global saat ini sebesar 22\% dari total penduduk dunia, dan dari sejumlah penyandang hipertensi tersebut hanya kurang dari seperlima yang melakukan upaya pengendalian terhadap tekanan darah. Di Indonesia berdasarkan RISKESDAS tahun 2018 dilaporkan prevalensi sebesar $34,11 \%$ dengan Sulawesi Utara berada di urutan ke-10 yakni sebesar $33,12 \%$, yang sebelumnya $15,0 \%$ pada tahun 2013 berdasarkan Riset Kesehatan Dasar Bada Litbangkes Kementerian Kesehatan RI. ${ }^{2,3}$

Peningkatan tekanan darah yang berkepanjangan dan berlangsung lama menyebabkan perubahan pada struktur otot jantung, arteri koroner, dan konduksi jantung antara lain gagal jantung, penyakit arteri koroner dan aritmia yang dikenal sebagai penyakit jantung hipertensi dengan manifestasinya berupa hipertrofi ventrikel kiri/ left ventricle hypertrophy $(\mathrm{LVH})$ pada hipertensi sistolik dan diastolik arteri sistemik. ${ }^{2,4}$

Left ventricle hypertrophy merupakan akibat dari pertumbuhan kardiomiosit sebagai respon terhadap beban hemo-dinamik berlebih guna mengembalikan otot jantung kembali normal dan untuk mempertahankan fungsi ventrikel kiri. Namun, hipertensi yang berkepanjangan dapat menyebabkan berbagai perubahan pada komponen kardiomiosit (apoptosis, fibrosis dan perubahan mikrosirkulasi) yang berkembang pada penyakit jantung hipertensi. ${ }^{5}$

Berdasarkan latar belakang tersebut, maka deteksi dan pengobatan yang tepat terhadap penyakit jantung hipertensi sangat penting. Oleh karena itu penulis tertarik melakukan literature review untuk membahas dan menelaah berbagai informasi ilmiah terkini mengenai diagnosis dan tatalaksana penyakit jantung hipertensi.

\section{METODE PENELITIAN}

Penelitian ini berbentuk literatur review dan data yang digunakan diperoleh melalui database berupa pubmed, clinical key, science direct, dan google scholar dengan menggunakan kata kunci (Hypertensive Heart Disease), (diagnosis of Hypertensive heart disease) OR (Screening of hypertensive heart disease) OR (imaging of hypertensive heart disease) AND (therapy OR treatment $O R$ management of hypertensive heart disease).

\section{HASIL PENELITIAN}

Setelah melalui tahap seleksi studi dari berbagai database didapatkan total 2400 artikel yang selanjutnya disaring berdasarkan kriteria inklusi sampai akhirnya diperoleh 10 literatur untuk dilakukan review.

Sebagian besar literatr tersebut menggunakan metode randomized controlled trial (RCT) dan sisanya berupa review article. Jumlah sampel dalam 10 literatur ini terdiri dari puluhan hingga ratusan pasien penyakit jantung hipertensi dari 7 negara yang berbeda. Tabel 1 memperlihatkan hasil kajian literatur yang digunakan dalam penelitian.

\section{BAHASAN \\ Diagnosis terkini penyakit jantung hipertensi}

Hasil penelitian dari 10 literatur yang telah diulas menunjukkan bahwa penyakit jantung hipertensi memerlukan pemeriksaan penunjang yang tepat dan akurat untuk diagnosis pasti. Selain tekanan darah yang tinggi, kelainan pada struktur miokardium yakni LVH, dilatasi ventrikel, disfungsi diastolik maupun sistolik, serta fibrosis miokard penting untuk dievaluasi sebagai menifestasi penyakit jantung hipertensi. Pada sebagian besar dari 10 jurnal tersebut, deteksi dilakukan dengan menggunakan elektrokardiogram (EKG), ekokardiografi dan cardiomagnetic resonance (CMR). 
Tabel 1. Hasil kajian literatur yang digunakan dalam penelitian

\begin{tabular}{|c|c|c|c|c|c|}
\hline No & $\begin{array}{l}\text { Peneliti/ } \\
\text { tahun }\end{array}$ & Judul literatur & Lokasi & Metode & Hasil/simpulan \\
\hline 1. & $\begin{array}{l}\text { Sujith } \\
\text { Kuruvilla et al } \\
(2014)^{6}\end{array}$ & $\begin{array}{l}\text { Increased extra- } \\
\text { cellular volume } \\
\text { and altered me- } \\
\text { chanics are asso- } \\
\text { ciated with LVH } \\
\text { in hypertensive } \\
\text { heart disease, not } \\
\text { hypertension } \\
\text { alone }\end{array}$ & $\begin{array}{l}\text { Charlottesville, } \\
\text { Virginia }\end{array}$ & $R C T$ & $\begin{array}{l}\text { - Deteksi fibrosis difus meng- } \\
\text { gunakan CMR dengan peng- } \\
\text { ukuran ECV pada pasien } \\
\text { hiper-tensi dengan LVH } \\
\text { - Pengukuran ECV dan native } \\
\text { T1 juga bermanfaat sebagai } \\
\text { metode baru untuk monitor } \\
\text { kemanjuran terapi pada } \\
\text { pasien hipertensi }\end{array}$ \\
\hline 2 & $\begin{array}{l}\text { Shoon H. } \\
\text { Chua et al } \\
(2020)^{7}\end{array}$ & $\begin{array}{l}\text { Phenotyping of } \\
\text { hypertensive } \\
\text { heart disease and } \\
\text { hypertrophic } \\
\text { cardiomyopathy } \\
\text { using perso- } \\
\text { nalized 3D } \\
\text { modelling and } \\
\text { cardiac cine MRI }\end{array}$ & $\begin{array}{l}\text { Kuala Lumpur, } \\
\text { Malaysia }\end{array}$ & $R C T$ & $\begin{array}{l}\text { Untuk membedakan etiologi } \\
\text { LVH pada penyakit jantung } \\
\text { hipertensi dan hipertrofi kardio- } \\
\text { miopati dapat tercermin dari } \\
\text { perbedaan fenotip yang dide- } \\
\text { teksi lewat CMR multipara- } \\
\text { metrik dengan teknik pemo- } \\
\text { delan 3D+ yang dipersonalisasi } \\
\text { memberikan info lokalis dan } \\
\text { segmental tentang geometri dan } \\
\text { dinamika jantung. }\end{array}$ \\
\hline 3 & $\begin{array}{l}\text { Makoto Saito } \\
\text { et al } \\
(2010)^{8}\end{array}$ & $\begin{array}{l}\text { The differences } \\
\text { in left ventricular } \\
\text { torsional beha- } \\
\text { vior between } \\
\text { patients with } \\
\text { hypertrophic } \\
\text { cardiomyopathy } \\
\text { and hypertensive } \\
\text { heart disease }\end{array}$ & $\begin{array}{l}\text { Toon Ehime, } \\
\text { Japan }\end{array}$ & $R C T$ & $\begin{array}{l}\text { Deteksi peak untwisting velo- } \\
\text { city relatif lebih tinggi semen- } \\
\text { tara peak torsion lebih rendah } \\
\text { pada pasien penyakit jantung } \\
\text { hipertensi dengan mengguna- } \\
\text { kan speckle tracking echo- } \\
\text { cardiography (STE). }\end{array}$ \\
\hline 4 & $\begin{array}{l}\text { Christopher } \\
\text { Schumann } \\
\text { et al } \\
(2019)^{9}\end{array}$ & $\begin{array}{l}\text { Recent advances } \\
\text { in imaging of } \\
\text { hypertensive } \\
\text { heart disease }\end{array}$ & $\begin{array}{l}\text { Charlottesville, } \\
\text { Virginia }\end{array}$ & $\begin{array}{l}\text { Article } \\
\text { review }\end{array}$ & $\begin{array}{l}\text { - Deteksi disfungsi sistolik } \\
\text { sub-klinis pada penyakit } \\
\text { jantung hipertensi menggu- } \\
\text { nakan STE } \\
\text { - deteksi fibrosis miokard } \\
\text { difus secara noninvasif } \\
\text { dengan T1 mapping CMR. }\end{array}$ \\
\hline 5 & $\begin{array}{l}\text { Maurizio } \\
\text { Golderisi } \\
(2012)^{10}\end{array}$ & $\begin{array}{l}\text { Changing pers- } \\
\text { pective in the } \\
\text { echocardiography } \\
\text { approach of } \\
\text { hypertensive } \\
\text { heart disease. }\end{array}$ & Naples, Italy & $\begin{array}{l}\text { Article } \\
\text { review }\end{array}$ & $\begin{array}{l}\text { Penilaian noninvasif terhadap } \\
\text { tekanan pengisian ventrikel kiri } \\
\text { dengan menggunakan STE } \\
\text { (speckle Tracking Echo- } \\
\text { cardiography). }\end{array}$ \\
\hline 6 & $\begin{array}{l}\text { Vasiliki V } \\
\text { Georgiopoulou } \\
\text { et al } \\
(2010)^{4}\end{array}$ & $\begin{array}{l}\text { Prevention, } \\
\text { diagnosis, and } \\
\text { treatment of } \\
\text { hypertensive } \\
\text { heart disease }\end{array}$ & $\begin{array}{l}\text { Atlanta, } \\
\text { Georgoria }\end{array}$ & $\begin{array}{l}\text { Article } \\
\text { review }\end{array}$ & $\begin{array}{l}\text { - Evaluasi LVH pada pasien } \\
\text { penyakit jantung hipertensi } \\
\text { dapat di deteksi dengan EKG, } \\
\text { ekokardiografi, CMR. } \\
\text { - Agen penghambat renin } \\
\text { angiotensin merupakan pende- } \\
\text { kataan paling efektif dalam } \\
\text { mengurangi regresi LVH. }\end{array}$ \\
\hline 7. & $\begin{array}{l}\text { Yasuhiko } \\
\text { Sakata et al } \\
(2014)^{11}\end{array}$ & $\begin{array}{l}\text { Clinical impacts } \\
\text { of additive use of } \\
\text { olmesartan in } \\
\text { hypertensive } \\
\text { patients with } \\
\text { chronic heart }\end{array}$ & Sendai, Japan & $\begin{array}{l}R C T \\
\text { (SUPPORT } \\
\text { trial) }\end{array}$ & $\begin{array}{l}\text { Penggunaan aditif olmesartan } \\
\text { tidak meningkatkan hasil klinis } \\
\text { melainkan memperburuk fungsi } \\
\text { ginjal pada pasien hipertensi } \\
\text { dengan CHF (Chronic Heart } \\
\text { Failure) terutama pada kombi- }\end{array}$ \\
\hline
\end{tabular}


failure

$\begin{array}{ll}\text { 8. Junichi } & \text { Effect of } \\ \text { Yamaguchi et } & \text { amlodipine } \\ \text { al } & \text { candesartan on } \\ (2010)^{12} & \text { cardiovascular } \\ & \text { events in } \\ & \text { hypertensive } \\ & \text { patients with } \\ & \text { coronary artery } \\ & \text { disease }\end{array}$

9. Peter M. Okin, Digoxin use and et al $(2015)^{13}$ risk of mortality in hypertensive patients with atrial fibrillation

10 M.U Moreno et al $(2018)^{14}$
Diagnosis and treatment of hypertensive heart disease

nasi 3 Obat yakni olmesartan, ACE-I dan $\beta$-blocker.

$\begin{array}{ll}\text { Tokyo, Japan } & \text { RCT (HIJ- } \\ & \text { CREATE } \\ & \text { study) }\end{array}$

New York, USA

Pamplona, Spain Article
review
Kombinasi terapi amlodipin dan candesartan mengurangi Major Adverse Cardiac Events (MACE) dibandingkan dengan terapi amlodipin dan non-ARB.

$R C T$ (LIFE Digoksin dapat digunakan study) dengan aman pada pasien hipertensi dengan fibrilasi atrium tanpa bahaya kematian yang nyata dan tidak ada peningkatan risiko kematian mendadak.

- EKG lebih spesifik dalam deteksi LVH pada pasien penyakit jantung hipertensi sementara ekokardiografi lebih sensitif.

- ARB, ACE-I, dan antagonis kalsium lebih efektif dibandingkan dengan diuretik dan $\beta$-blocker dalam mengurangi massa ventrikel kiri,
Pada penelitian Moreno et al $^{14}$ ekokardiografi memiliki sensitivitas lebih tinggi dibanding EKG (88\% vs 50\%) namun lebih spesifik daripada ekokardiografi $(95 \%$ vs $84 \%$ ). Dalam studi perbandingan dengan CMR, sensitivitas EKG hanya 25\% dibanding CMR. Berdasarkan karakteristik sensitivitas dan spesifisitas tersebut, EKG tidak bisa disebut sebagai tes definitif untuk diagnosis LVH, sehingga diperlukan pencitraan lebih lanjut. ${ }^{4}$

Sampai saat ini CMR masih dianggap sebagai baku emas dalam evaluasi volume dan massa ventrikel kiri serta efektif digunakan untuk deteksi fibrosis miokard difus. Seperti pada penelitian Kuruvilla et $\mathrm{al}^{6}$ yang menunjukkan bahwa hipertensi dengan LVH memiliki fibrosis difus yang lebih besar melalui deteksi CMR dengan pengukuran extracellular volume (ECV) dibandingkan dengan yang hipertensi non-LVH.

Extracellular volume secara bermakna meningkat pada subjek hipertensi dengan
LVH ( $\mathrm{p}<0.01)$, demikian pula dengan pengukuran Native $T 1$ yang didapatkan lebih memanjang $(\mathrm{p}=0,007)$ pada subjek hipertensi dengan LVH. ${ }^{6}$ Hasil penelitian tersebut sejalan juga dengan yang dilaporkan oleh Schumann et al. ${ }^{9}$

Selain deteksi fibrosis miokard dengan T1 mapping dalam artikel review oleh Schumann et $\mathrm{al}^{9}$ juga terdapat kemajuan terbaru dalam diagnosis penyakit jantung hipertensi yakni pada perkembangan ekokardiografi speckle tracking echocardiography (STE) yang digunakan untuk mengukur global dan regional strain, yang didefinisikan sebagai derajat perpindahan selama siklus jantung, melalui penanda akustik yang dihasilkan oleh efek USG pada miokardium. Dalam artikel review tersebut terdapat beberapa penelitian yang menyatakan bahwa STE dapat digunakan untuk mendeteksi disfungsi sistolik subklinis pada pasien hipertensi dengan fraksi ejeksi normal. 
Dalam artikel review oleh Schumann et $\mathrm{al}^{9}$ pada pemeriksaan terhadap longitudinal, circumferential dan radial strain berdasarkan geometri ventrikel kiri pasien hipertensi, didapatkan bahwa longitudinal strain secara bermakna menurun pada pasien dengan hipertrofi dibanding subjek kontrol (konsentrik $-15,1 \pm 4,0 \%$, eksentrik $15,9 \pm 4,4 \%$ vs kontrol $-18,9 \pm 3,3 \%$; $p<0,05) .{ }^{9}$ Dengan menggunakan teknik STE tersebut kerusakan awal global longitudinal strain (GLS) dapat diamati pada stadium prahipertensi dan pada hipertensi yang baru pertama kali didiagnosis ketika fraksi ejeksi masih normal. ${ }^{10}$

Dalam menegakkan diagnosis penyakit jantung hipertensi sering kali sulit membedakannya dengan hipertrofi cardiomiopati (HCM), karena keduanya mengalami hipertrofi ventrikel kiri serta disfungsi diastolik meskipun fungsi sistolik normal. Hal ini sesuai dengan penelitian Saito et $\mathrm{al}^{8}$ dan Galderisi ${ }^{10}$ yang membedakan torsi ventrikel kiri antara pasien penyakit jantung hipertensi dengan HCM menggunakan kemajuan terbaru dari ekokardiografi yakni STE.

Dalam penelitiannya, Galderisi ${ }^{10}$ melaporkan bahwa STE 2 dimensi sudah memungkinkan untuk penilaian non-invasif torsi ventrikel kiri dengan resolusi waktu yang tinggi memungkinkan pengukuran peak torsion serta waktu rotasi. Pada parameter rotasi ventrikel kiri dalam sistolik, peak torsion pada penyakit jantung hipertensi dan HCM meningkat secara

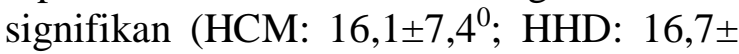
$6.2^{0}$; kontrol: $11,5 \pm 4,5^{0}$ ) sedangkan pada parameter rotasi ventrikel kiri dalam diastolik, peak untwisting velocity lebih meningkat dibanding HCM (HCM: $98 \pm 48^{\%}$ s HHD: $124 \pm 46 \%$ s; kontrol: $86 \pm 21 \%$ s). Mereka mengoreksi peak untwisting velocity dengan peak torsion karena torsi ventrikel kiri merupakan penentu utama rekoil elastisitas dan ini berpengaruh besar terhadap peak untwisting velocity. Dengan kata lain peak untwisting velocity relatif tinggi pada penyakit jantung hipertensi meskipun peak torsion lebih besar pada HCM. Peak torsion yang meningkat pada pasien penyakit jantung hipertensi mungkin sebagian seba- gai kompensasi terhadap disfungsi diastolik yang terganggu. ${ }^{8}$

Selain pemeriksaan ekokardiografi 2D, ada pula real time $3 D$ echocardiography (RT3DE). Namun saat ini penggunaannya masih terbatas terutama karena tingginya biaya transduser 3D dan perangkat lunak khusus yang diperlukan. Selain itu nilai titik potong spesifik massa ventrikel kiri dengan menggunakan teknologi ini masih harus ditetapkan. ${ }^{10}$

Penelitian terbaru juga dilakukan Chuah et $\mathrm{al}^{7}$ yang melaporkan bahwa untuk membedakan etiologi LVH bisa menggunakan CMR multiparametrik dengan cara membandingkan perbedaan fenotipikal dari penyakit jantung hipertensi dengan HCM. Mereka menggunakan teknik 3D+time personalized $L V$ models yang memberikan informasi lokalis dan segmental mengenai pola geometri dan dinamika jantung juga karakteristik penyakit jantung hipertensi dan hipertrofi kardiomiopati.

Dalam membedakan fenotip tersebut, sebanyak 5 dari 15 variabel merupakan yang paling bermakna dalam membedakan etiologi LVH tersebut, diantaranya end diastolic wall thikness (EDWT) max, longitudinal strain (LS), massa/volume (M/V), dan massa dimana EDWT max memiliki skor tertinggi yakni $5 / 5$. Pasien dengan penyakit jantung hipertensi sebagian besar memiliki segmen EDWT max kategori $9 \mathrm{~mm}<\max$ EDWT $<15 \mathrm{~mm}$ menunjukan hipertrofi yang terlihat pada segmen inferior basal, tengah dan apikal, sementara segmen sisanya (terutama segmen apikal) memiliki EDWT max kategori normal yakni $<9 \mathrm{~mm}^{7}{ }^{7}$

\section{Tatalaksana terkini penyakit jantung hipertensi}

Berdasarkan ulasan dari literatur didapatkan bahwa agen penghambat reninangiotensin yakni ACE-I atau ARB masih menjadi pendekatan yang paling efektif untuk mengurangi regresi LVH pada pasien penyakit jantung hipertensi. Menurut pedoman American heart association (AHA)/ American college of cardiology (ACC) terapi nonfarmakologi yakni dengan menerapkan pola dietary approaches to stop hypertension 
(DASH), penurunan berat badan, mengurangi asupan garam berlebih, olahraga teratur dan mengurangi konsumsi alkohol. ${ }^{15}$

Sementara pada terapi farmakologi, ACE-I bekerja dengan menghambat mekanisme angiotensin I ke angiotensin II yang merupakan vasokonstriktor yang dapat meningkatkan retensi garam dan air. Agen penghambat ACE ini pada akhirnya akan menyebabkan vasodilatasi dan mencegah terbentuknya cairan yang menghasilkan pelepasan aldosteron. ${ }^{16}$ Selain itu ACE-I juga berperan dalam menghambat metabolisme bradikinin, yang merupakan vasodilator berasal dari kininogen yang diubah oleh kalkrein menjadi bradikinin. Bradikinin yang menumpuk akibat dihambat oleh ACE-I menyebabkan vasodilatasi sehingga bradikinin akan berikatan dengan reseptor $\mathrm{BK}_{2}$ di pembuluh darah dan mengaktifkan produksi prostaglandin yang juga nantinya menyebabkan vasodilatasi. Peningkatan bradikinin tersebut dapat berikatan dengan reseptor batuk di bronkus sehingga menyebabkan batuk sebagai efek samping dari ACE-I. ${ }^{16,17}$

Kaptopril berperan dalam menghambat enzim pengubah yaitu peptidil dipeptidase yang menghidrolisis angiotensin I menjadi angiotensin II dan menginaktifkan bradikinin. Tidak seperti vasodilator langsung, obat ini tidak mengaktivasi refleks simpatis dan aman digunakan pada orang dengan iskemik. ${ }^{17}$

Berbeda halnya dengan ARB yang bekerja dengan mengikat reseptor angiotensin II dan menghambat angiotensin II juga mendorong produksi aldosteron yang meningkatkan natrium dan air. ARB tidak menghalangi kerusakan bradikinin yang menyebabkan batuk sehingga dikatakan lebih selektif dibandingkan dengan ACE-I. Losartan dan valsartan merupakan yang pertama kali di pasarkan. ${ }^{16,17}$

ACE yang mampu menghasilkan angiotensin II, oleh karena itu berpotensi menghambat total efek angiotensin dibanding ACE-I. ${ }^{16,17}$

Georgiopoulou et $\mathrm{al}^{4}$ melaporkan bahwa semua golongan antihipertensi mengurangi regresi $\mathrm{LVH}$, namun golongan ACE-I,
ARB dan CCB lebih efektif dibandingkan dengan $\beta$-blocker, sementara diuretik lebih efektif dari $\beta$-blocker namun tidak lebih manjur dari ACE-I. Pada pasien penyakit jantung hipertensi, ACE-I selain mengurangi massa ventrikel kiri juga mengurangi fibrosis miokard, meningkatkan fungsi diastolik ventrikel kiri, ${ }^{14}$ serta telah terbukti menurunkan morbiditas dan mortalitas pada pasien gagal jantung akibat disfungsi sistolik. $^{4}$

ARB umumnya digunakan sebagai alternatif bila terdapat intoleransi ACE-I salah satu yang dilaporkan adalah losartan lebih efektif dibandingkan amlodipin dalam mengurangi apoptosis kardiomiosit dan fibrosis miokard pada pasien penyakit jantung hipertensi. Namun penggunaan ARB pada pasien HFrEF dengan riwayat hipertensi masih kontroversial. ${ }^{14}$

Peneltian Sakata et $\mathrm{al}^{11}$ menunjukan bahwa penggunaan aditif olmesartan tidak meningkatkan hasil klinis tapi malah memperburuk fungsi ginjal pada pasien hipertensi dengan gagal jantung kronik. Kejadian primary endpoint tidak menurun pada kelompok olmesartan yakni 33.2\% dibandingkan kelompok kontrol 29,2\% [hazard ratio (HR) 1,18; Convidence Interval $95 \%$ (CI) $0,96-1,46 ; \quad \mathrm{P}=0,112]$, sementara disfungsi ginjal juga berkembang lebih sering pada kelompok olmesartan $16.8 \%$ vs kelompok kontrol 10,7\% [HR 1,64; CI 1,19-2,26; $\mathrm{P}=0,03] .{ }^{11}$

Kejadian primary endpoint tersebut berkaitan juga dengan kombinasi 3 obat yakni olmesartan, ACE-I dan $\beta$-blocker, sedangkan pada kombinasi 2 obat yakni olmesartan dengan ACE-I berkaitan dengan penurunan onset baru fibrilasi atrium sementara olmesartan dan $\beta$-blocker dikaitkan dengan penurunan mortalitas tanpa perkembangan disfungsi ginjal. ${ }^{11}$ Oleh karena itu kombinasi 2 obat terutama olmesartan dengan $\beta$-blocker lebih baik sementara dua blokade terhadap RAAS gagal menurunkan mortalitas melainkan malah menimbulkan efek samping yang berlebihan. ${ }^{12}$

Mengenai pasien hipertensi yang disertai dengan penyakit arteri koroner pada penelitian Yamaguchi et $\mathrm{al}^{12}$ dikatakan 
bahwa kombinasi amlodipin dengan kandesartan dapat mengurangi kejadian kardiovaskular dibanding kombinasi amlodipin dengan non-ARB. ${ }^{12}$ Tekanan darah sistolik dan diastolik rerata untuk 2 kelompok ialah $135,2 / 75,1$ pada kelompok amlodipin dan kandesartan sementara amlodipin dengan kelompok non-ARB rata-rata 135,1/74,8. sedangkan untuk kejadian primary endpoint pada kelompok amlodipin dengan kandesartan 21,8\% sementara amlodipin dan nonARB 32,1\% [HR: 0,$61 ; 95 \%$ CI: 0,41$0,91] .{ }^{12}$

Hasil studi tersebut menunjukkan bahwa amlodipin dan kandesartan mengurangi kejadian kardiovaskular dibandingkan pengobatan amlodipin dengan non-ARB, meskipun tidak terdapat perbedaan bermakna antara tekanan darah sistolik dan diastolik kedua kelompok. Diketahui bahwa pada pasien CAD dengan hipertensi, sensitivitas tinggi kandesartan terhadap protein $\mathrm{C}$ reaktif, IL-6 dan aktivitas platelet memiliki efek penghambatan yang lebih jelas daripada ACE-1 ataupun ARB lain. ${ }^{12}$

Penelitian mengenai fibrilasi atrium juga sangat erat kaitannya dengan hipertensi. Berdasarkan beberapa pedoman, kombinasi 2 agen antihipertensi seperti ACEI/ARB dengan $\beta$-blocker/CCB non-DHP merupakan lini pertama tatalaksana hipertensi dengan fibrilasi atrium.

Menurut Okin et $\mathrm{al}^{13}$ penggunaan digoksin untuk mengontrol laju pada pasien fibrilasi atrium dengan hipertensi dikatakan aman tanpa bahaya mortalitas yang nyata serta tidak ada peningkatan risiko kematian mendadak. Dalam studi tersebut antara pengukuran awal dan akhir selama penelitian, pasien yang menggunakan digoksin mengalami penurunan denyut jantung yang lebih besar secara bermakna, peningkatan durasi QRS, serta penurunan regresi LVH.

Hubungan penggunaan digoksin dengan angka kematian dalam penelitian tersebut dilaporkan bahwa pasien yang diobati dengan digoksin memiliki beban faktor risiko kardiovaskular yang lebih tinggi serta semua penyebab kematian dibandingkan dengan pasien yang tidak pernah menggunakan digoksin selama penelitian. Namun hal tersebut tidak secara bermakna terkait dengan mortalitas kardiovaskular atau semua penyebab kematian setelah disesuaikan dengan faktor risiko dan skor kecenderungan penggunaan digoksin yang menunjukan bahwa peningkatan risiko univariat mungkin mencerminkan kecenderungan yang lebih besar pada penggunaan digoksin pasien risiko tinggi fibrilasi atrium dibandingkan peningkatan risiko kematian yang sebenarnya dari digoksin. ${ }^{13}$

\section{SIMPULAN}

Pada penyakit jantung hipertensi kelainan struktural yang sering ditemukan ialah hipertrofi ventrikel kiri (konsentrik maupun eksentrik), dilatasi ventrikel kiri, disfungsi diastolik dan sistolik, yang dapat dideteksi lewat pemeriksaan EKG, ekokardiografi, rontgen toraks, dan CMR.

Terapi penyakit jantung hipertensi menurut pedoman ACC/AHA yakni nonfarmakologik seperti pola diet DASH dan terapi farmakologik pilihan yaitu ACE-I atau ARB.

Diharapkan penelusuran penelitian terkini terus dilakukan setiap tahun mengenai diagnosis penyakit jantung hipertensi agar diperoleh metode-metode diagnostik terbaru yang lebih akurat dan efektif. Perlu adanya edukasi lebih lanjut dari tenaga kesehatan kepada masyarakat mengenai pentingnya pengendalian terhadap tekanan darah lewat terapi non farmakologik maupun farmakologik. Bagi tenaga medis diharapkan lebih mempertimbangkan penggunaan obat-obat yang diberikan beserta efek sampingnya.

\section{Konflik Kepentingan}

Penulis menyatakan tidak terdapat konflik kepentingan dalam studi ini.

\section{DAFTAR PUSTAKA}

1. Yogiantoro M. Pendekatan klinis hipertensi. In: Setiati S, Alwi I, Sudoyono A, Simadibrata M, editors. Ilmu Penyakit Dalam Papdi (6th ed). Jakarta: Interna Publishing, 2014; p. 2259-83.

2. Kemenkes RI. Situasi kesehatan jantung. Pus data dan Inf Kementeri Kesehat RI 
[Internet]. 2014;3. Available from: http://www.depkes.go.id/download.php ?file=download/pusdatin/infodatin/info datin-jantung.pdf

3. Riset Kesehatan Dasar. Badan Litbangkes Kementerian Kesehatan RI. Pus data dan Inf Kementeri Kesehat RI. 2014;3.

4. Georgiopoulou VV, Kalogeropoulos AP, Raggi $\mathrm{P}$, Butler J. Prevention, diagnosis, and treatment of hypertensive heart disease. Cardiol Clin. 2010;28(4):675-91. Available from: http://dx.doi.org/10.1016/ j.ccl.2010.07.005

5. Rampengan SH. Buku Praktis Kardiologi. Jakarta: Fakultas Kedokteran Universitas Indonesia, 2014.

6. Kuruvilla S, Janardhanan R, Antkowiak P, Keeley EC, Adenaw N, Brooks J, et al. Increased extracellular volume and altered mechanics are associated with $\mathrm{LVH}$ in hypertensive heart disease, not hypertension alone. JACC Cardiovasc Imaging. 2015;8(2):172-80.

7. Chuah SH, Md Sari NA, Chew BT, Tan LK, Chiam YK, Chan BT, et al. Phenotyping of hypertensive heart disease and hypertrophic cardiomyopathy using personalized 3D modelling and cardiac cine MRI. Phys Medica. 2020;78(May): 137-49. Available from: https://doi.org/ 10.1016/j.ejmp.2020.08.022

8. Saito M, Okayama H, Yoshii T, Hiasa G, Sumimoto $\mathrm{T}$, Inaba $\mathrm{S}$, et al. The differences in left ventricular torsional behavior between patients with hypertrophic cardiomyopathy and hypertensive heart disease. Int $\mathbf{J}$ Cardiol. 2011;150(3):301-6. Available from: http://dx.doi.org/10.1016/j.ijcard.2010. 04.040

9. Schumann CL, Jaeger NR, Kramer CM. Recent advances in imaging of hypertensive heart disease. Curr Hypertens Rep. 2019;21(1):3.

10. Galderisi M. Changing perspectives in the echocardiographic approach of hypertensive heart disease. J Cardiovasc Echogr. 2012;22(1):21-8. Available from: $\quad h t t p: / / d x . d o i . o r g / 10.1016 / j$. jcecho.2011.12.001
11. Sakata Y, Shiba N, Takahashi J, Miyata S, Nochioka K, Miura M, et al. Clinical impacts of additive use of olmesartan in hypertensive patients with chronic heart failure: The supplemental benefit of an angiotensin receptor blocker in hypertensive patients with stable heart failure using olmesartan (SUPPORT) trial. Eur Heart J. 2015;36(15):915-23.

12. Yamaguchi J, Hagiwara N, Ogawa H, Koyanagi $\mathrm{R}$, Kasanuki $\mathrm{H}$, Takagi $\mathrm{A}$, et al. Effect of amlodipine + candesartan on cardiovascular events in hypertensive patients with coronary artery disease (from the Heart Institute of Japan Candesartan Randomized Trial for Evaluation in Coronary Artery Disease [HIJ-CREATE] study). Am J Cardiol. 2010;106(6):819-24. Available from: http://dx.doi.org/10.1016/j.amjcard.201 0.05 .007

13. Okin PM, Hille DA, Wachtell K, Kjeldsen SE, Boman K, Dahlöf B, et al. Digoxin use and risk of mortality in hypertensive patients with atrial fibrillation. J Hypertens. 2015;33(7):1480-6.

14. Moreno M, Gonzales A, Lopez B, Ravasa S, Beaumont J, Jose G. Hypertensive Heart Disease. Elsevier, 2018.

15. Whelton PK, Carey RM, Aronow WS, Casey DE, Collins KJ, Himmelfarb CD, et al. 2017 ACC/AHA/AAPA/ABC/ACPM/ AGS/APhA/ASH/ASPC/NMA/PCNA guideline for the prevention, detection, evaluation, and management of high blood pressure in adults a report of the American College of Cardiology/ American Heart Association Task Force on Clinical pr. Hypertension. 2018; 71(6):1269-324.

16. Rampengan SH. Kapita Selekta: Kardiologi. Jakarta: Badan Penerbit FKUI, 2018.

17. Katzung BG, Masters SB, Trevor AJ. Basic and Clinical Pharmacology (12th ed). New York: McGrawHill, 2012; p. 173-4.

18. Felmeden DC, Lip GYH. Resistant hypertension and the Birmingham hypertension square. Curr Hypertens Rep. 2001;3(3):203-8. 